\title{
Enhancement of manganese extraction in a biochar-enriched bioleaching column with a mixed culture of indigenous bacteria
}

\author{
ENDAH RETNANINGRUM ${ }^{1, \boldsymbol{v}}$ WAHYU WILOPO ${ }^{2}$, I WAYAN WARMADA ${ }^{2}$ \\ ${ }^{1}$ Microbiology Laboratory, Faculty of Biology, Universitas Gadjah Mada. Jl. Teknika Selatan, Sekip Utara, Sleman 55281, Yogyakarta, Indonesia. \\ Tel./fax.: +62-274-580839, `email: endahr@ugm.ac.id \\ ${ }^{2}$ Department of Geological Engineering, Faculty of Engineering, Universitas Gadjah Mada. Jl. Grafika No. 2, Bulaksumur, Sleman 55281, Yogyakarta, \\ Indonesia
}

Manuscript received: 20 February 2021. Revision accepted: 29 April 2021.

\begin{abstract}
Retnanimgrum E, Wilopo W, Warmada IW. 2021. Enhancement of manganese extraction in a biochar-enriched bioleaching column with a mixed culture of indigenous bacteria. Biodiversitas 22: 2949-2955. Biochar can improve manganese ore extraction during bioleaching by inducing redox reactions and providing a porous matrix for bacterial attachment. In this research, the effect of variations in biochar concentration on the performance of a bioleaching column with a mixed culture of Acidithiobacillus sp. KL3 and Bacillus niacini KB3B1 were studied comprehensively for 30 days. Addition of $0.4 \%$ biochar resulted in $89 \%$ manganese extraction. Bioleaching with biochar promoted the oxidation of sulfur and yielded high sulfate concentrations, much better $\mathrm{pH}$, and excellent oxidation-reduction potential conditions. The bacteria in the mixed culture survived and adapted to the extreme column environment by releasing extracellular polymeric substance, as evidenced by the sharp increase in the content of the material in the column to $135.7 \mathrm{mg} / \mathrm{g}$ over 30 days of incubation. The synergistic effect of the bacteria in the mixed culture greatly contributed to the mechanism of manganese extraction in the column, as indicated by changes in relative bacterial abundance, which is related to bacterial community succession during bioleaching. The relative abundance of B. niacini KB3B1 gradually increased and peaked at $30 \%$ over 9 days of measurements. By comparison, the abundance of Acidithiobacillus sp. KL3 first decreased over 9 days of bioleaching and then increased to a maximum of $80 \%$ in the final stages of the process. This finding reveals that biochar addition could enhance the mechanisms of bioleaching and improve the yield of manganese extraction.
\end{abstract}

Keywords: Acidithiobacillus sp. KL3, Bacillus niacin KB3B1, catalyst, EPS, relative abundance

\section{INTRODUCTION}

Indonesia is home to many valuable metal ores, including manganese ore, spread over several of its islands. Manganese ore must be adequately and efficiently processed to improve the national economy while ensuring environmental sustainability. A practical, efficient, and environment-friendly approach for treating manganese ore is bioleaching; this method has been successfully applied to process ores in a number of nations, including the United States of America, England, Japan, Australia, China, and Germany (Banerjee et al. 2017; Kaksonen et al. 2020; Lan et al. 2020; Newsome et al. 2020). According to many studies, two types of bacteria are involved in the bioleaching of manganese ore, namely sulfur-oxidizing bacteria and heterotrophic bacteria. (Xin et al. 2015; Dan et al. 2016; González et al. 2018; Zhang et al. 2018). Previous research provided some suitable strains of sulfur-oxidizing bacteria (e.g., Acidithiobacillus sp. KL3) and heterotrophic bacteria (e.g., Bacillus niacini KB3B1), both of which were isolated from river sediments containing sulfur in Kedongsongo, Semarang, Indonesia. The isolates of these species have been successfully used to enhance bioleaching ability in shake flasks following optimization of the size, amount and type of manganese ore and environmental conditions (e.g., $\mathrm{pH}$, temperature) (Retnaningrum and Wilopo 2019; Prasidya et al. 2019). The addition of a catalyst in the form of carbonaceous materials, i.e., biochar, has also been observed to enhance the bioleaching reaction (Wang et al. 2018; Kadivar et al. 2021).

Biochar can facilitate electron transfer and, consequently, promote redox reactions. This material's high porosity also provides a suitable matrix onto which bacteria can attach for bioleaching (Kan et al. 2020; Yang et al. 2020; Anto et al. 2021; Das et al. 2021). Biochar is a biomass pyrolysis byproduct characterized by high carbon and inorganic material contents (Chang et al. 2016; Ma et al. 2017; Bonsu et al. 2020). Palm kernel shell is abundant biomass obtained from oil palm wastes used for biochar production.

Previous researchers showed that mixed cultures of sulfur-oxidizing and heterotrophic bacteria could better increase manganese extraction yields compared with pure cultures during bioleaching (Zhu et al. 2014; Hao et al. 2016). The increase in extraction of manganese by mixed cultures is greatly influenced by the interactions of the bacteria, particularly their synergistic effects. Sulfuroxidizing bacteria can provide organic components for use by heterotrophic bacteria in the form of lysates or exudates. In addition, the metal-extraction mechanisms of these two groups of bacteria are different. Sulfur-oxidizing bacteria can extract metals from the ore by acidolysis and redoxolysis. Metal extraction via acidolysis may be attributed to these bacteria's ability to synthesize $\mathrm{H}_{2} \mathrm{SO}_{4}$ 
(Ilyas and Lee 2014). Redoxolysis occurs via oxidationreduction (ORP) reactions. Ferric ions are enzymatically reduced under anaerobic conditions; in this process, hydrogen or sulfur serves as the electron donor, and energy is provided during redoxolysis for microbial growth (Hubau et al. 2018). The metal-extraction mechanism of heterotrophic bacteria occurs through complexolysis to produce cyanogen (Lu and $\mathrm{Xu} 2016$ )

During bioleaching, the column environment tends to develop extreme conditions due to acidic $\mathrm{pH}$ and high levels of sulfate and soluble manganese. These conditions could induce bacterial cells to release extracellular polymeric substance (EPS) as a form of cell defense (Hu et al. 2020). EPS is a complex compound with a high molecular weight; it consists of a large proportion of polysaccharides and smaller proportions of other compounds, such as proteins, uronic acids, humic substances, and lipids. Biosynthetic EPS can exist as attached capsular substances or slime on the surface of bacterial cells. Besides providing cell protection against extreme environments, EPS also functions as a carbon and energy source (Gupta and Diwan 2017; Wang et al. 2018).

Given its low cost, easy operation, and high yield, industrial-scale metal extraction via heap bioleaching is considered a highly effective technology (Shiers et al. 2016). The heap bioleaching method can be simulated at the laboratory scale by using a bioleaching column, which represents an intermediate bioleaching scale-up process that can be implemented prior to commercial scale-up (Jia et al. 2019). Research on metal extraction using a biocharenriched bioleaching column with a mixed culture of Acidithiobacillus sp. KL3 and B. niacin KB3B1 could provide a reliable model and essential information to estimate the bioleaching results for commercial heap bioleaching operations. Thus, the present study's objectives are to investigate the effects of biochar on the performance of a bioleaching column for manganese extraction with a mixed bacterial culture and characterize bacterial adaptation and bacterial community succession during the bioleaching process.

\section{MATERIALS AND METHODS}

\section{Ore sample, biochar, and bacteria}

Ore samples of pyrolusite were collected from Kliripan, Kulon Progo, Yogyakarta, Indonesia. The samples contained $30.4 \% \mathrm{Fe}, 25 \% \mathrm{Mn}$, and $34.0 \% \mathrm{~S}$. The particle size of the samples ranged from $0.16 \mathrm{~mm}$ to $0.125 \mathrm{~mm}$. The biochar used in this study was obtained from a local market in Bantul Regency, Yogyakarta, and produced from coconut shell charcoal chemically activated by $\mathrm{ZnCl}_{2}$ and $\mathrm{Na}_{2} \mathrm{CO}_{3}$ and then pyrolyzed at $700^{\circ} \mathrm{C}$ for 4 hours. The obtained biochar was ground into particles with diameters ranging from $0.8 \mathrm{~mm}$ to $1 \mathrm{~mm}$. The physicochemical properties of the biochar included $79 \%$ total carbon, $1 \%$ total $\mathrm{N}, 1.8 \%$ total $\mathrm{H}, 2.3 \%$ ash content, $0.38 \%$ moisture content, iodine number $450 \mathrm{mg} / \mathrm{g}, 403 \mathrm{~m}^{2} / \mathrm{g}$ surface area, and $\mathrm{pH} 8 \pm 0.3$.

Two bioleaching strains, namely, the heterotrophic bacterium B. niacin KB3B1 and the chemolithotrophic bacterium Acidithiobacillus sp. KL3, were isolated from sulfuric river sediments and used in this experiment (Retnaningrum and Wilopo 2019; Prasidya et al. 2019). The bacteria were routinely cultivated in $9 \mathrm{~K}$ medium

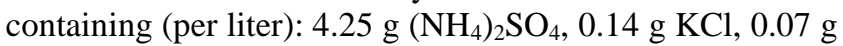
$\mathrm{K}_{2} \mathrm{HPO}_{4}, 0.7 \mathrm{~g} \mathrm{MgSO}_{4} \cdot 7 \mathrm{H}_{2} \mathrm{O}$, and $0.02 \mathrm{~g} \mathrm{Ca}\left(\mathrm{NO}_{3}\right)_{2} \cdot 4 \mathrm{H}_{2} \mathrm{O}$.

\section{Bioleaching experiments}

The bioleaching experiment was conducted in polypropylene tubes measuring $50 \mathrm{~cm}$ in height and $5 \mathrm{~cm}$ in diameter. The column setup is shown in Figure 1 and consisted of (A) plate on which to lay the manganese ore at the bottom of the column, (B) an external bioreactor containing the feeding solution, (C) a stirrer for proper mixing of the feeding solution in the external bioreactor, (D) a peristaltic pump to pump the feeding solution, (E) a liquid distributor at the top of the column for consistent delivery of the leaching solution to the manganese ore, $(F)$ an air compressor to supply air for bacterial growth, (G) an air filter, (H) an air inlet, (I) a gas outlet, and (J) a connector to recirculate the leaching solution.

As much as $500 \mathrm{~g}$ of manganese ore and various amounts of biochar $(0.2 \%, 0.4 \%$, and $0.6 \%)$ of weight $(\mathrm{g} / \mathrm{g})$ were loaded onto the support plate of the column. The column was fed with a solution containing the mixed bacterial culture at a flow rate of $10 \mathrm{~mL} \mathrm{~min}^{-1}$ from the top of a bioreactor. The feeding solution was prepared by inoculating $20 \%(\mathrm{v} / \mathrm{v})$ mixed bacterial inoculum with a cell number in the range of $10^{7}-10^{8} \mathrm{CFU} / \mathrm{mL}$ into $80 \%(\mathrm{v} / \mathrm{v}) 9 \mathrm{~K}$ medium. That flow rate was controlled by the peristaltic pump, and the bacterial solution was recycled continuously and fed to the column for 30 days (Abhilash et al. 2013; Wu et al. 2016; Jalali et al. 2019). Leached samples were periodically collected at intervals of 3 days to analyze bioleaching performance, bacterial adaptation, and bacterial community succession.

\section{Bioleaching performance}

Leached samples were collected at fixed time intervals for 30 days, and their sulfate concentration, $\mathrm{pH}$, ORP, and manganese concentration were measured. The $\mathrm{pH}$ of the samples was measured by a $\mathrm{pH}$ meter (pHS-3C, Leici, China), and ORPs were measured with a platinum electrode with reference to an $\mathrm{Ag} / \mathrm{AgCl}$ electrode by using an ORP meter (Hanna HI 8512). The concentration of sulfates was determined using a spectrophotometer (wavelength, $420 \mathrm{~nm}$ ) on the basis of a turbidimetric assay. Extracted manganese concentrations were determined by a flame atomic absorption spectrophotometer (Hitachi, Z2000) (Khayatin et al. 2018). Optimal bioleaching performance was further observed in terms of bacterial adaptability and succession in the community. 


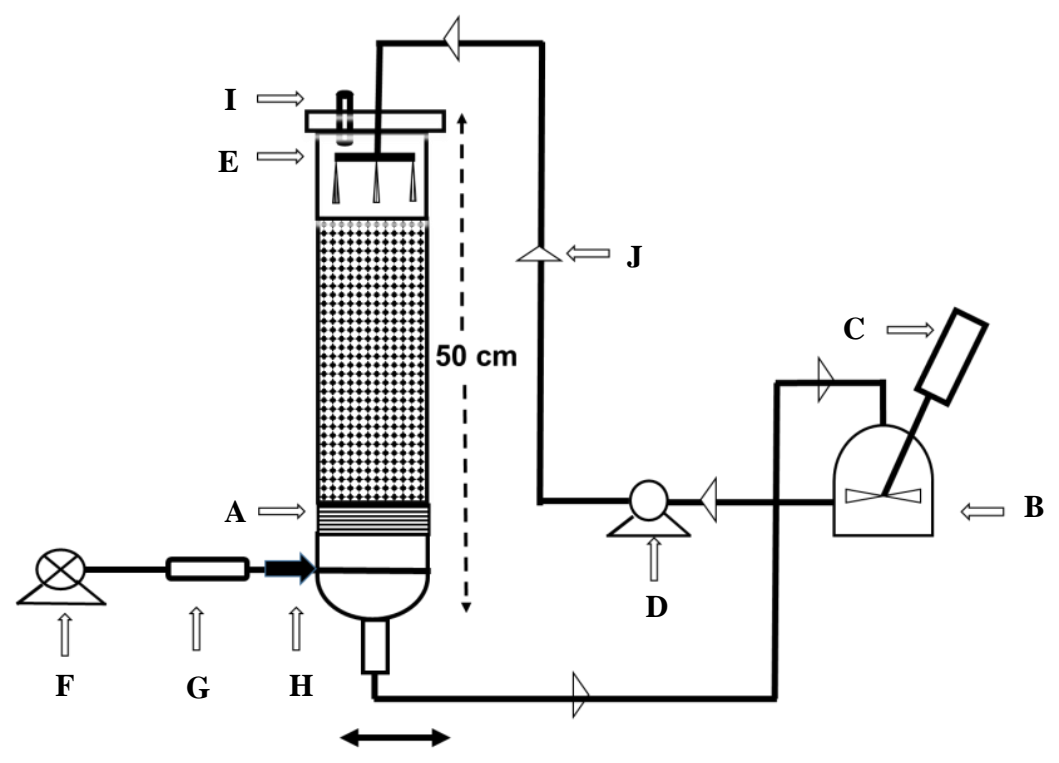

Figure 1. Bioleaching column design. A. Plate, B. Bioreactor, C. Stirrer, D. Peristaltic pump, E. Liquid distributor, F. Air compressor, G. Air filter, H. Air inlet, I. Gas outlet, J. Connector

Bacterial adaptation in the bioleaching column was analyzed by observing the chemical characteristics of EPS that had accumulated as biofilms during bioleaching. Leaching solution samples obtained from several continuously operated bioleaching systems were allowed to stand for 1.5 hours, after which the thickened sludge was centrifuged at $1500 \mathrm{rpm}$ and $4^{\circ} \mathrm{C}$ for $20 \mathrm{~min}$. The resulting pellet samples were suspended in distilled water and then lysed using $1 \mathrm{~g}$ of glass beads (diameter, $0.2 \mathrm{~mm}$ ). Thereafter, the samples were shaken in a vortex at 1400 rpm for $10 \mathrm{~min}$. Lysed samples were extracted with a mixed solution containing equal concentration of $10 \mathrm{mM}$ Tris-HCl (pH 7), 10 mM N-dodecyl- $N, N$-dimethyl-3ammonio-1-propanesulfonate, and $1 \mathrm{mM}$ EDTA at $4^{\circ} \mathrm{C}$. The extracted samples were centrifuged and passed through $0.2 \mu \mathrm{m}$ membrane filters, after which the extracted EPS was collected. The dry weight of the extracted EPS was determined prior to biochemical characterization for the presence of carbohydrates and proteins. The Bradford assay was used to determine protein contents with bovine serum albumin as the standard (Bradford 1976). Total carbohydrate contents were measured using the phenolsulfuric acid assay with glucose as the standard (Dubois et al. 1956). The carbohydrate and protein contents of the sample were then determined using a spectrophotometer.

\section{Bacterial community succession}

Total DNA was extracted from $10 \mathrm{~g}$ of leached samples by using an Isoil for Beads Beating Kit (Nippon Gene, Tokyo, Japan). DNA extraction was carried out according to the manufacturer's instructions with minor modifications. The quantity and quality of DNA extracts were measured using a UV-Vis Nanodrop spectrophotometer (Thermo Scientific) to determine the DNA concentration and DNA/protein ratio. The pure DNA extract was adjusted to a concentration of $100 \mathrm{ng} \mu \mathrm{L}^{-1}$. The target distinct regions
(16SV3-V4) of the bacterial 16S rDNA genes were then amplified by PCR using the specific primers $341 \mathrm{~F}$ (5'CCTACGGGA GGCAGCAG-3') and 806 R (3'GGACTACYVGGG TATCTAAT-5').

The PCR products were sequenced using the Illumina MiSeq platform and their sequencing results were then calculated with the Quantitative Insights into Microbial Ecology (QIIME 1.7.0) program. Prior to statistical analysis, low-quality or unclear reads were excluded. The sequences were then categorized using the Ribosomal Database Project classifier with a $60 \%$ confidence cut-off and grouped into operational taxonomic units (OTUs) at $97 \%$ similarity. The Greengenes database was used to search the taxonomic classification of each representative sequence OTU which was operated using the SILVA 16S rRNA gene database (DeSantis et al. 2006). Bacterial community successions were analyzed at the species level. The relative proportion of bacterial abundance was then determined by dividing the number of reads by the number of sequences found per sample by using Microsoft Excel.

\section{Statistical analysis}

All experiments were conducted in triplicate, and the results are expressed as mean \pm standard deviation. Mean treatment values were compared by one-way analysis of variance, and Duncan's multiple range test was employed to test mean differences. Differences in treatment results were considered significant at $\mathrm{p}<0.05$.

\section{RESULTS AND DISCUSSION}

\section{Bioleaching performance}

Acidithiobacillus sp. KL3 and Bacillus niacini KB3B1 were assessed, as shown in Figure 2. The addition of biochar significantly increased the samples' sulfate 
concentration over 30 days of incubation $(p<0.05)$. The sulfate content of the column could be attributed to Acidithiobacillus sp. KL3, which oxidizes sulfur from manganese ore to sulfate. Sulfate formation during the bioleaching of metal ores has been observed in several studies (Figueroa-Estrada et al. 2020; Pattanaik et al. 2020). The sulfate concentration in all treatments increased with increasing incubation time. Moreover, among the treatments established in the present study, that with $0.4 \%$ biochar showed the highest increase in sulfate concentration. In the column enriched with $0.4 \%$ biochar, approximately $7500 \mathrm{mg} / \mathrm{mL}$ sulfate was quickly produced within 7 days; by comparison, the columns enriched with $0.6 \%$ and $0.2 \%$ biochar revealed sulfate contents of 5800 and $6160 \mathrm{mg} / \mathrm{mL}$, respectively, over 18 days. The increase in sulfate concentration in the control occurred very slowly; indeed, only $3000 \mathrm{mg} / \mathrm{mL}$ sulfate was produced in control over 21 days.

The oxidation of sulfur to sulfuric acid during column bioleaching by Acidithiobacillus sp. KL3 over 30 days of incubation resulted in a significant increase in ORP ( $\mathrm{p}<$ 0.05). Among the columns established, that $0.4 \%$ biochar addition revealed the fastest increase in ORP. The ORP of the column enriched with $0.4 \%$ biochar achieved steady ORPs of $645-650 \mathrm{mV}$ on day 21 . Therefore, the addition of
$0.4 \%$ biochar improves oxidation conditions for the bioleaching of manganese. Biochar addition apparently accelerates the oxidation of sulfur to sulfate, which accumulates over the course of bioleaching.

Sulfate production by Acidithiobacillus sp. KL3 induced decreases in $\mathrm{pH}$ over 30 days of bioleaching ( $\mathrm{p}<$ 0.05). A previous study indicated that B. niacini KB3B1 produces cyanide by consuming acids during bioleaching, thereby causing a decrease in the $\mathrm{pH}$ of the solution in the column (Prasidya et al. 2019). The $\mathrm{pH}$ of the solution reached a steady value of 1.29 earlier (day 21) in the column added with $0.4 \%$ biochar compared with that added with $0.2 \%$ biochar and the control (day 27). The $\mathrm{pH}$ of the solution also reached a steady value of 1.14 earlier (day 21) in this column compared with that added with $0.6 \%$ biochar (day 24).

As the bioleaching time increased to 30 days, increases in sulfate concentration accompanied by increases in ORP and decreases in $\mathrm{pH}$ increased the extraction of manganese on the ore by the mixed bacterial culture. The bioleaching reactions were described by Mahmoud et al. (2017) as follows:

$$
\begin{aligned}
& 2 \mathrm{~S}^{0}+\mathrm{O}_{2}+2 \mathrm{H}_{2} \mathrm{O} \rightarrow 2 \mathrm{H}_{2} \mathrm{SO}_{4} \\
& 2 \mathrm{MS}+2 \mathrm{H}_{2} \mathrm{SO}_{4}+\mathrm{O}_{2} \rightarrow 2 \mathrm{MSO}_{4}+2 \mathrm{~S}^{0}+2 \mathrm{H}_{2} \mathrm{O}
\end{aligned}
$$

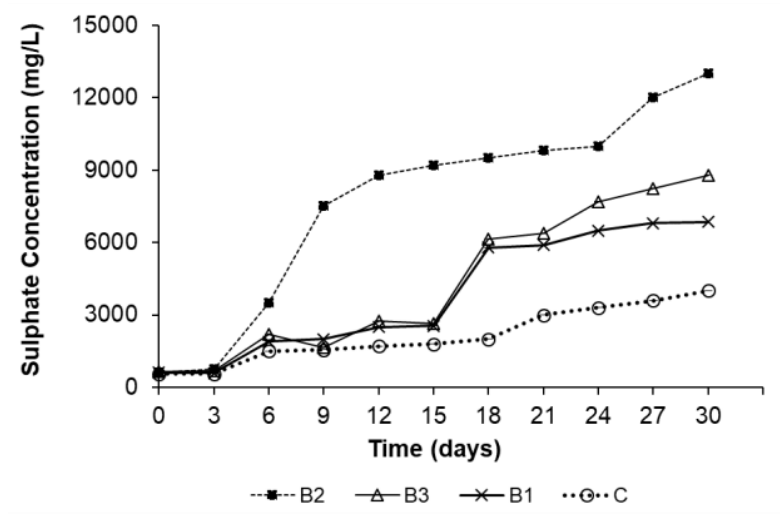

A

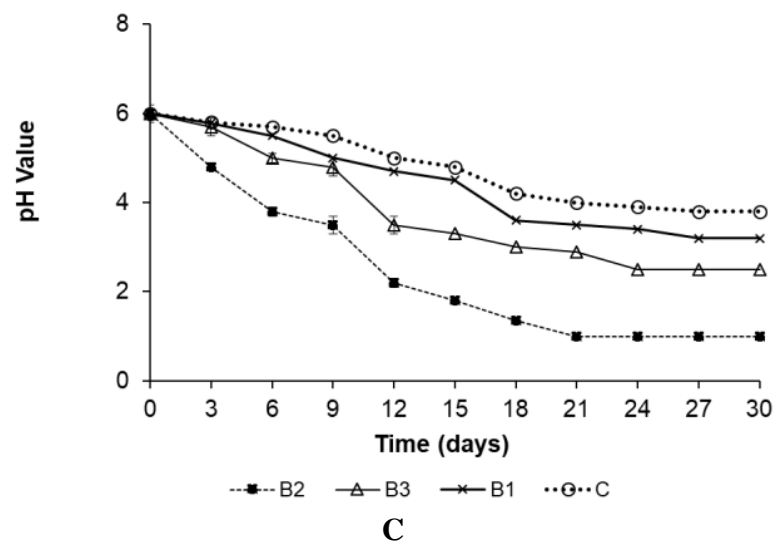

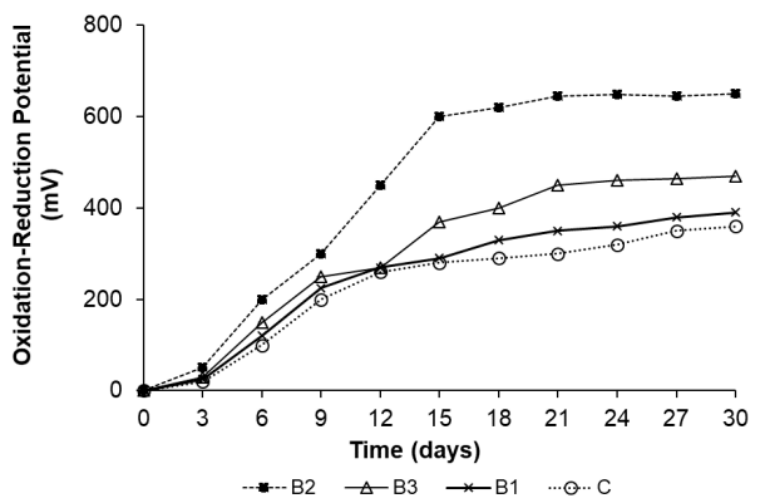

B

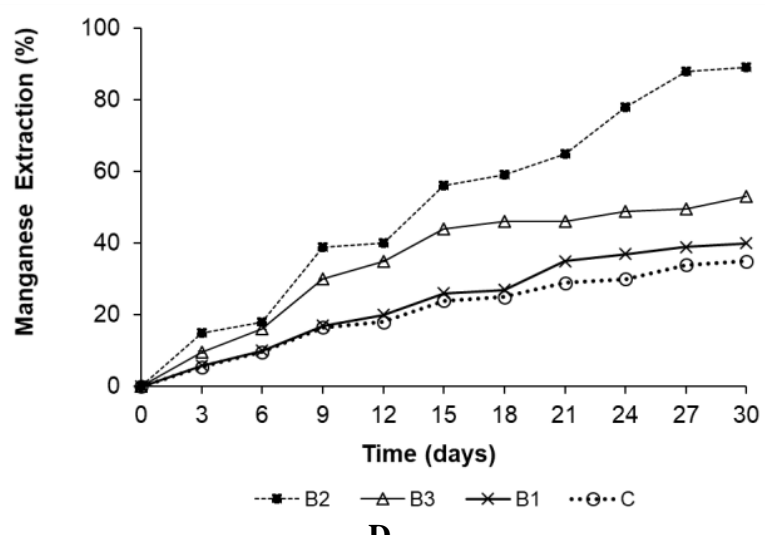

D

Figure 2. Changes in sulfate concentration (A), ORP (B), $\mathrm{pH}(\mathrm{C})$, and manganese extraction (D) during column bioleaching by a mixed culture of indigenous bacteria with biochar addition. Note: B: Biochar addition, B1: $0.2 \%$; B2: 0.4\%; B3: 0.6\%. C: without biochar addition 
In this study, addition of biochar significantly accelerated manganese extraction $(p<0.5)$. In fact, the addition of $0.4 \%$ biochar yielded the highest increase in manganese extraction, followed by additions of $0.6 \%$ and $0.2 \%$ biochar. The control revealed slow manganese extraction. Addition of $2 \%$ biochar resulted in the extraction of $39 \%$ manganese within 9 days and a maximum extraction rate of $89 \%$ manganese after 30 days. A similar trend was observed when $0.6 \%$ biochar was added, i.e., as much as $30 \%$ manganese was rapidly extracted within 9 days. After this initial rapid extraction, a steady increase in extraction rate to $53 \%$ was observed on day 30 . However, the addition of $0.2 \%$ biochar induced only approximately $20 \%$ manganese extraction after 12 days, and a maximum yield of $40 \%$ manganese was observed at the end of bioleaching (30 days). These findings show that the addition of $0.4 \%$ biochar accelerates manganese extraction during column bioleaching with a mixed bacterial culture to optimal levels. Previous research demonstrated that the high porosity of biochar provides a microhabitat for the attachment of bacteria in the mixed culture to support their growth. Biochar could also promote electron transfer in the oxidation reaction of sulfur to sulfate by Acidithiobacillus sp. KL3, thereby allowing the rapid extraction of manganese ore (Wang et al. 2016; Xu et al. 2016; Zhao et al. 2016).

\section{Analysis of bacterial adaptation}

Enrichment of the bioleaching column with $0.4 \%$ biochar encouraged the bacteria in the mixed culture to adapt to the extreme environment in the column by producing EPS, as shown in Figure 3. Specifically, the bacteria in the mixed culture generated $37.78 \mathrm{mg} / \mathrm{g}$ EPS over 3 days. EPS production then increased rapidly and achieved a steady concentration of approximately 133.4 $\mathrm{mg} / \mathrm{g}$ over a period of 24 days. The EPS collected was mainly composed of carbohydrates and low levels of protein, which is in accordance with findings from previous investigations (Gupta and Diwan 2017; Wang et al. 2018). Besides defending cells against extreme environments, the EPS produced by the bacteria in the mixed culture also enhances manganese ore extraction via an EPS-mediated

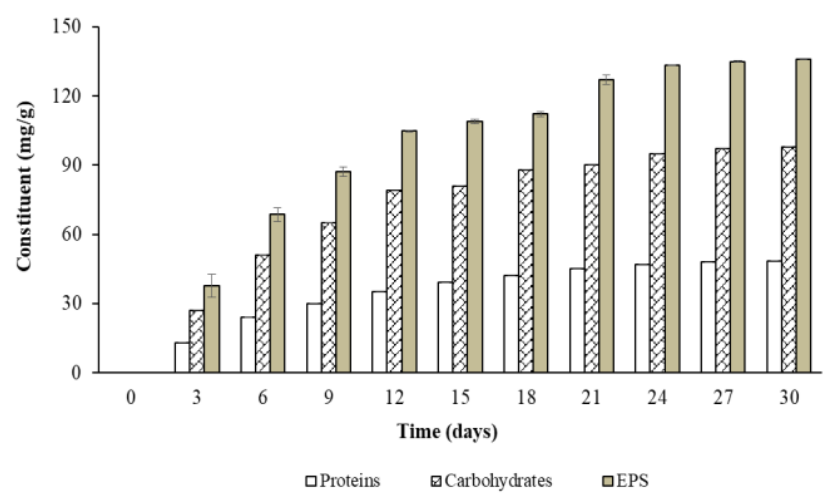

Figure 3. Variations in EPS concentration and constituents obtained from the bioleaching column enriched with $0.4 \%$ biochar at intervals of 3 days. mechanism (Zhang et al. 2015). During column bioleaching, EPS promotes the attachment of bacteria to the surface of manganese ore, which, in turn, enhances manganese extraction. Therefore, the increase in EPS production during column bioleaching is directly proportional to the increase in the extractable concentration of manganese.

The EPS produced by the bacteria in the mixed culture accumulated on the mineral surface in the form of biofilms as bioleaching progressed. The biofilm phase is one of the adaptative mechanisms of bacteria during metal bioleaching. This phase provides a protective microenvironment against extreme conditions, so that bacterial metabolism exceeds that of the planktonic phase. Other than bioleaching columns, the formation of biofilms has also been observed in microbial fuel cells and sulfatereducing bioreactors (Retnaningrum and Wilopo 2016; Retnaningrum and Wilopo 2017).

\section{Bacterial community succession}

The succession of the bacterial community in the bioleaching column significantly influenced the effects of metal extraction (Yin et al. 2019; Zhou et al. 2019). This finding is related to the dominance of certain bacterial strains that develop during bioleaching. The dominance of the bacterial strains during bioleaching with $4 \%$ biochar treatment was investigated on the basis of relative abundances, as shown in Figure 4.

At the initial stages of bioleaching, the ratio of Acidithiobacillus sp. KL3 to B. niacin KB3B1 inoculated into the column bioreactor was adjusted to $1: 1$. Therefore, the relative abundance of each strain showed an equivalent yield of $50 \%$. From day 3 to day 9 , the relative abundance of B. niacini KB3B1 increased from $55 \%$ to $65 \%$, while that of Acidithiobacillus sp. KL3 decreased from $45 \%$ to $35 \%$. However, the relative abundance of B. niacin KB3B1 decreased by $60 \%$ on day 12 to $24 \%$ on day 30. By contrast, on day 12 , the relative abundance of Acidithiobacillus sp. KL3 increased by $40 \%$ and peaked at $80 \%$ on day 30 . The shift in the relative abundance of the two type strains was induced by their synergistic bioleaching mechanism in the column (Panda et al. 2017).

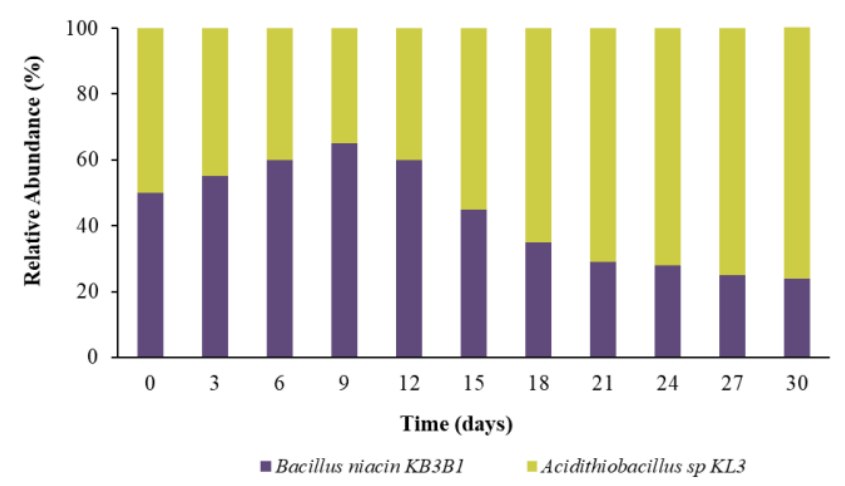

Figure 4. Bacterial community succession during $0.4 \%$ biocharenriched column bioleaching with a mixed culture of indigenous bacteria. 
At the early stages of bioleaching, Acidithiobacillus sp. KL3 supports $B$. niacin KB3B1 growth by releasing metabolites as organic compounds. As these metabolites accumulate, the relative abundance of $B$. niacin increases. However, as bioleaching proceeds, the dominant strain on the mineral surface shows evident changes. Acidithiobacillus sp. had the highest relative abundance at the end of the bioleaching process. This phenomenon may be attributed to the improved adaptability of Acidithiobacillus sp. compared with Bacillus sp. to highORP and low-pH conditions (Bajkic et al. 2013; Avdalovic et al. 2015).

Pearson correlation coefficients were used to describe the correlation between strains and various physicochemical parameters, as shown in Table 1. The relative abundance of Acidithiobacillus sp. KL3 was significantly and positively correlated with manganese extraction, ORP, and EPS but negatively correlated with $\mathrm{pH}(\mathrm{p}<0.05)$. By comparison, B. niacin KB3B1 showed significantly positive correlations with manganese extraction and ORP but negative correlations with $\mathrm{pH}$ and EPS ( $\mathrm{p}<0.05)$. As a result, managing the synergistic effects of microorganisms, such as different functional types of bacterial strains, is critical in regulating and controlling bioleaching performance.

Analyses of bioleaching performance, bacterial adaptation, and bacterial community succession during column bioleaching demonstrated that the addition of biochar to the column system with two types of bacteria in the mixed culture promotes the extraction of manganese. The findings indicate that biochar acts as a catalyst for redox reactions and provides a porous matrix for bacterial attachment during the bioleaching process. The addition of $0.4 \%$ biochar led to $89 \%$ manganese extraction, which is $54 \%$ higher than the manganese extraction rate observed during column bioleaching without biochar. The addition of biochar to the bioleaching column is beneficial and a cost-effective solution to enhance manganese extraction during bioleaching. Further exploration of column bioleaching technology with mixed cultures of indigenous bacteria and biochar enrichment at the field scale is necessary to determine whether its implementation at the industrial scale is environmentally sustainable and costeffective.

Table 1. Pearson correlation coefficients of the relative abundance and physicochemical parameters of two bacterial strains during column bioleaching with a mixed culture of indigenous bacteria and $0.4 \%$ biochar enrichment

\begin{tabular}{lcc}
\hline Physicochemical parameters & $\begin{array}{c}\text { Acidithiobacillus } \\
\text { sp. KL3 }\end{array}$ & $\begin{array}{c}\text { Bacillus niacin } \\
\text { KB3B1 }\end{array}$ \\
\hline & & \\
Manganese extraction & $0.6791^{*}$ & $0.7231^{*}$ \\
pH & $-0.5449^{*}$ & $-0.5637^{*}$ \\
Oxidation-reduction potential & $0.5142^{*}$ & $0.5433^{*}$ \\
Extracellular polymeric substance & $0.4188^{*}$ & $-0.4614^{*}$
\end{tabular}

Note: *: significant at $\mathrm{p}<0.05$

\section{ACKNOWLEDGEMENTS}

This study was sponsored by KEMENRISTEK DIKTI Indonesia under Contract Nos. AMD/E1/KP.PTNBH/2020 and 2798/UN1.DITLIT/DIT-LIT/PT/2020. We thank Serafica Btari Christiyani Kusumaningrum and Denaya Andrya Prasidya for providing us with the bacterial strains used in our experiments.

\section{REFERENCES}

Abhilash, Pandey BD, Singh AK. 2013. Comparative performance of uranium bioleaching from low-grade Indian apatite rock in column and bioreactor. Energy Procedia 39: 20-32. DOI: 10.1016/j.egypro.2013.07.188.

Andriyanto, Wilopo W, Retnaningrum E. 2020. The Performance of a fixed-bed anaerobic bioreactor using sulfate-reducing bacterial consortium from Sikidang Crater Sediments. Indon J Chem 20 (1): 190-199. DOI: 10.22146/ijc.45164.

Anto S, Sudhakar MP, Ahamed TS, Samuel MS, Mathimani T, Brindhadevi K, Pugazhendhi A. 2021. Activation strategies for biochar to use as an efficient catalyst in various applications. Fuel 285: 119205. DOI: 10.1016/j.fuel.2020.119205.

Avdalovic J, Beskoski V, Gojgic-Cvijovic G, Mattinen ML, Stojanovi M, Zildzovic S, Vrvic MM. 2015. Microbial solubilization of phosphorus from phosphate rock by iron-oxidizing Acidithiobacillus sp. B2. Min Eng 72: 17-22. DOI: 10.1016/j.mineng.2014.12.010.

Bajkic S, Narancic T, Djokic L, Djordjevic D, Nikodinovic-Runic J, Moric I, Vasiljevic B. 2013. Microbial diversity and isolation of multiple metal-tolerant bacteria from surface and underground pits within the copper mining and smelting complex. Bor Arch Biol Sci 65: 375-386. DOI: 10.2298/ABS1301375B.

Banerjee I, Burrell B, Reed C, West AC, Banta S. 2017. Metals and minerals as a biotechnology feedstock: engineering biomining microbiology for bioenergy applications. Curr Opin Biotechnol 45:144-155. DOI: 10.1016/j.copbio.2017.03.009.

Bonsu BO, Takase M, Mantey J. 2020. Preparation of charcoal briquette from palm kernel shells: case study in Ghana. Heliyon 6: e05266. DOI: 10.1016/j.heliyon.2020.e05266.

Bradford MM. 1976. A rapid and sensitive method for the quantitation of microgram quantities of protein utilizing the principle of protein-dye binding. Anal Biochem 7(72): 248-54. DOI: 10.1006/abio.1976.9999.

Chang G, Huang Y, Xie J, Yang H, Liu H, Yin X, Wu C. 2016. The lignin pyrolysis composition and pyrolysis products of palm kernel shell, wheat straw, and pine sawdust. Energy Convers Manag 124: 587-597. DOI: 10.1016/j.enconman.2016.07.038.

Dan Z, Zhang Y, Cai J, Li X, Duan N, Xin B. 2016. Reductive leaching of manganese from manganese dioxide ores by bacterial-catalyzed twoores method. Intl J Miner Process 150: 24-31 DOI: 10.1016/j.minpro.2016.03.0070.

Das SK, Ghosh GK, Avasthe R. 2021. Applications of biomass-derived biochar in modern science and technology. Environ Technol Innov 21: 101306. DOI: 10.1016/j.eti.2020.101306.

DeSantis TZ, Hugenholtz P, Larsen N, Rojas M, Brodie EL, Keller K. 2006. Greengenes, a chimera-checked 16S rRNA gene database and workbench compatible with ARB. Appl Environ Microbiol 72: 50695072. DOI: 10.1128/AEM.03006-05.

Dubois M, Gilles KA, Hamilton JK, Rebers PA, Smith F. 1956. Colorimetric method for determination of sugars and related substances. Anal Chem 28 (3): 350-356. DOI: 10.1021/ac60111a017.

Figueroa-Estradaa JC, Aguilar-Lópeza R, Rodríguez-Vázqueza R, NeriaGonzález MI. 2020. Bioleaching for the extraction of metals from sulfide ores using a new chemolithoautotrophic bacterium. Hydrometallurgy 197: 105445. DOI: 10.1016/j.hydromet.2020.105445.

Gupta P, Diwan B. 2017. Bacterial exopolysaccharide mediated heavy metal removal: A review on biosynthesis, mechanism and remediation strategies. Biotechnol Rep 13: 58-71. DOI: 10.1016/j.btre.2016.12.006.

Gonzáleza E, Rodríguez JM, Muñoz JA, Blázquez ML, Ballester A, González F. 2018. The contribution of Acidiphilium cryptum to the 
dissolution of low-grade manganese ores. Hydrometallurgy 175: 312318 DOI: 10.1016/j.hydromet.2017.12.008.

Hao X, Liang Y, Yin H, Ma L, Xiao Y, Liu Y, Qiu G, Liu X. 2016. The effect of potential heap construction methods on column bioleaching of copper flotation tailings containing high levels of fines by mixed cultures. Miner Eng 98: 279-285. DOI: 10.1016/j.mineng.2016.07.015.

Hu W, Feng S, Tong Y, Zhang H, Yang H. 2020. Adaptive defensive mechanism of bioleaching microorganisms under extremely environmental acid stress: Advances and perspectives. Biotechnol Adv 42: 107580. DOI: 10.1016/j.biotechadv.2020.107580.

Hubau A, Minier M, Chagnes A, Joulian C, Pereza C, Guezennec A. 2018. Continuous production of a biogenic ferric iron lixiviant for the bioleaching of printed circuit boards (PCBs). Hydrometallurgy 180: 180-191. DOI: 10.1016/j.hydromet.2018.07.001.

Ilyas S, Lee J. 2014. Biometallurgical recovery of metals from waste electrical and electronic equipment: a review. Chem Bio Eng Rev 1 (4). DOI: $10.1002 /$ cben.201400001.

Jia Y, Tan Q, Sun H, Zhang Y, Gao H, Ruan R. 2019. Sulfide mineral dissolution microbes: Community structure and function in industrial bioleaching heaps. Green Energy Environ 4(1): 29-37. DOI: 10.1016/j.gee.2018.04.001.

Jalali F, Fakhari J, Zolfaghari A. 2019. Response surface modeling for lab-scale column bioleaching of low-grade uranium ore using a new isolated strain of Acidithiobacillus ferridurans. Hydrometallurgy 185: 194-203. DOI: 10.1016/j.hydromet.2019.02.014.

Kadivar S, Pourhossein F, Mousavi SM. 2021. Recovery of valuable metals from spent mobile phone printed circuit boards using biochar in indirect bioleaching. J Environ Manag 280: 111642. DOI: 10.1016/j.jenvman.2020.111642.

Kaksonen AH, Deng X, Bohu T, Zea L, Khaleque HN, Gumulya Y, Boxall NJ, Morris C, Cheng KY. 2020. Prospective directions for biohydrometallurgy. Hydrometallurgy 195: 105376. DOI: 10.1016/j.hydromet.2020.105376.

Khan A, Khan S, Lei M, Alam M, Khan MA, Khan A. 2020. Biochar characteristics, applications and importance in health risk reduction through metal immobilization. Environ Technol Innov 20: 101121 DOI: 10.1016/j.eti.2020.101121.

Khayatian G, Moradi M, Hassanpoor S. 2018. $\mathrm{MnO}_{2} / 3 \mathrm{MgO}$ nanocomposite for preconcentration and determination of trace copper and lead in food and water by flame atomic absorption spectrometry. J Anal Chem 73: 470-478. DOI: 10.1134/S1061934818050088

Lan J, Sun Y, Du Y, Du D, Zhang TC, Li J. 2020. Environmentallyfriendly bioleaching of manganese from pyrolusite: Performance and mechanisms. J Clean Prod 249: 119354. DOI: 10.1016/j.jclepro.2019.119354.

Lu Y, Xu Z. 2016. Precious metals recovery from waste printed circuit boards: A review for current status and perspective. Resour Conserv Recy 113: 28-39. DOI: 10.1016/j.resconrec.2016.05.007.

Ma Z, Yang Y, Ma Q, Zhou H, Luo X, Liu X, Wang S. 2017. Evolution of the chemical composition, functional group, pore structure and crystallographic structure of bio-char from palm kernel shell pyrolysis under different temperatures. J Anal Appl Pyrol 127: 350-359. DOI 10.1016/j.jaap.2017.07.015.

Mahmoud A, Cezac P, Hoadley AFA, Contamine F, D'Hugues P. 2017. A review of sulfide minerals microbially assisted leaching in stirred tank reactors. Intl Biodeterior Biodegradation 119: 118-146. DOI: 10.1016/j.ibiod.2016.09.015

Newsome L, Arguedas AS, Coker VS, Boothman C, Lloyd JR. 2020. Manganese and cobalt redox cycling in laterites; Biogeochemical and bioprocessing implications. Chem Geol 531: 119330. DOI: 10.1016/j.chemgeo.2019.119330

Panda S, Akcil A, Mishra S, Erust C. 2017. Synergistic effect of biogenic $\mathrm{Fe}^{3+}$ coupled to $\mathrm{S}^{0}$ oxidation on simultaneous bioleaching of $\mathrm{Cu}$, Co, $\mathrm{Zn}$ and As from hazardous pyrite ash waste. J Hazard Mater 325: 5970. DOI: 10.1016/j.jhazmat.2016.11.050

Pattanaik A, Sukla LB, Pradhan D, Krishna Samal DPK. 2020. Microbial mechanism of metal sulfide dissolution. Mater Today Proc 30: 326331. DOI: 10.1016/j.matpr.2020.01.615.

Prasidya DA, Wilopo W, Warmada IW, Retnaningrum E. 2019. Optimization of manganese bioleaching activity and molecular characterization of indigenous heterotrophic bacteria isolated from the sulfuric area. Biodiversitas 20 (7): 1904-1909. DOI: $10.13057 /$ biodiv/d200716

Retnaningrum E, Wilopo W. 2016. Performance and bacterial composition of anodic biofilms in microbial fuel cell using dairy wastewater. AIP Conf Proc 1744 (1): 020018. DOI: 10.1063/1.4953492.

Retnaningrum E, Wilopo W. 2017. Removal of sulphate and manganese on synthetic wastewater in sulphate reducing bioreactor using Indonesian natural zeolite. Indones J Chem 17 (2): 203-210 DOI: 10.22146/ijc.22710

Retnaningrum E, Wilopo W. 2019. Pyrolusite bioleaching by an indigenous Acidithiobacillus sp. KL3 isolated from an Indonesian sulfurous river sediment. Indonesia J Chem 19 (3): 712-719. DOI: 10.22146/ijc.38898.

Shiers DW, Collinson DM, Watling HR. 2016. Life in heaps: A review of microbial responses to variable acidity in sulphide mineral bioleaching heaps for metal extraction. Res Microbiol 167 (7): 576586. DOI: 10.1016/j.resmic.2016.05.007.

Wang S, Yue Z, Yan W, Chen L, Mahadevan GD, Feng Z. 2016. Enhanced bioleaching efficiency of metals from E-wastes driven by biochar. J Hazard Mater 320: 393-400. DOI: 10.1016/j.jhazmat.2016.08.054.

Wang J, Tian B, Bao Y, Qian C, Yang Y, Niu T, Xin B. 2018. Functional exploration of extracellular polymeric substances (EPS) in the bioleaching of obsolete electric vehicle $\mathrm{LiNi}_{\mathrm{x}} \mathrm{CoyMn}_{-\mathrm{x}-\mathrm{y}} \mathrm{O}_{2} \mathrm{Li}$-ion batteries. J Hazard Mater 354: 250-257. DOI: 10.1016/j.jhazmat.2018.05.009.

Wang Y, Chen X, Zhou H. 2018. Relationships between galvanic interaction, copper extraction and community dynamics during bioleaching of chalcopyrite by a moderately thermophilic culture. Bioresour Technol 265: 581-585.

Wu ZL, Zou LC, Chen JH, Lai XK, Zhu YG. 2016. Column bioleaching characteristic of copper and iron from Zijinshan sulfide ores by acid mine drainage. Intl J Miner Process 149: 18-24. DOI: 0.1016/j.minpro.2016.01.015.

Xu S, Adhikari D, Huang R, Zhang H, Tang Y, Roden EE, Yang Y. 2016. Biochar facilitated microbial reduction of hematite. Environ Sci Technol 2389-2395. DOI: 10.1021/acs.est.5b05517.

Yang H, Chen Z, Chen W, Chen Y, Wang X, Chen H. 2020. Role of porous structure and active $\mathrm{O}$-containing groups of activated biochar catalyst during biomass catalytic pyrolysis. Energy 210: 118646. DOI: 10.1016/j.energy.2020.118646.

Yin S, Chen W, Chen X, Wang L. 2019. Bacterial-mediated recovery of copper from low-grade copper sulphide using acid-processed rice straw. Bioresour Technol 288: 121605. DOI: 10.1016/j.biortech.2019.121605.

Zhang RY, Neu TR, Bellenberg S, Kuhlicke U, Sand W, Vera M. 2015. Use of lectins to in situ visualize glycoconjugates of extracellular polymeric substances in acidophilic archaeal biofilms. Microb Biotechnol 8 (3): 448-461. DOI.10.1111/1751-7915.12188.

Zhang L, Donga H, Liu Y, Bian L, Wang X, Zhou Z, Huang Y. 2018. Bioleaching of rare earth elements from bastnaesite-bearing rock by actinobacteria. Chem Geol 483: 544-557. DOI: 10.1016/j.chemgeo.2018.03.023.

Zhao Z, Zhang Y, Holmes DE, Dang Y, Woodard TL, Nevin KP, Lovley DR. 2016. Potential enhancement of direct interspecies electron transfer for syntrophic metabolism of propionate and butyrate with biochar in up-flow anaerobic sludge blanket reactors. Bioresour Technol 209: 148-156. DOI: 10.1016/j.biortech.2016.03.005.

Zhou W, Wu J, Zeng W, Wang Y, Guo N, Zhang L, Wan L, Zhou H. 2019. Optimization of mixed cultivation of the moderate thermophilic bioleaching microorganisms for high cell density using statistical methodology. Geomicrobiol J 36 (3): 224-231. DOI: $10.1080 / 01490451.2018 .1536176$.

Zhu J, Zhang J, Li Q, Han T, Hu Y, Liu X, Qin W, Chai L, Qiu G. 2014. Bioleaching of heavy metals from contaminated alkaline sediment by auto- and heterotrophic bacteria in stirred tank reactor. Trans Nonferrous Met Soc China 24 (9): 2969-2975. DOI: 10.1016/S10036326(14)63433-6. 